\title{
Financial inclusion and micro, small, and medium enterprises (MSMEs) growth in Uganda
}

\author{
Corti Paul Lakuma $^{1 *}$ (D, Robert Marty ${ }^{2}$ and Fred Muhumuza ${ }^{3}$
}

\author{
* Correspondence: cortipaul@ \\ hotmail.com \\ ${ }^{1}$ Economic Policy Research Centre, \\ Makerere University Kampala, P.O. \\ Box 7841, Kampala, Uganda \\ Full list of author information is \\ available at the end of the article
}

\begin{abstract}
This paper draws on data from Uganda's 2013 World Bank Enterprise Survey (WBES), which comprises data on 762 firms across Uganda to assess the effects of the business environment, with particular interest on the impact of finance on firm growth by focusing on differences across firm size. Unlike past studies, we use firm level data that allows us to interrogate whether the impact of the business environment is unbiased across firm size. Most importantly, this paper mitigates the risk of the potential measurement error, omitted variable bias, and endogeneity. The results suggest that micro, small, and medium enterprises (MSMEs) in Uganda benefit more from financial access than large firms. These effects are stronger and more sustained among medium firms. The paper interprets these results as evidence that MSMEs are more credit constrained relative to large firms. The paper also discerns that while informality and poor regulatory environment may help divert economic activity from large firms to MSMEs, informality increases the vulnerability of MSMEs to corruption to sustain their informal and invisible status. The policy implication on size, efficiency, and dynamism of the business sector in Uganda is that there is a need to increase not only financial inclusion of MSMEs but also improve the general business environment, particularly the formalization of micro firms.
\end{abstract}

Keywords: Financial inclusion, Entrepreneurship, Employment, Growth, MSMEs

\section{Introduction}

Extensive evidence shows that investment climate and in particular financial inclusion is critical to firm growth. ${ }^{1}$ This issue is even more important in developing countries where markets and institutional infrastructure are less developed (Aterido, Hallward-Driemeier, \& Pagés, 2009). Olawale and Garwe (2010) identify lack of finance as a key factor constraining micro, small, and medium enterprises (MSMEs) growth in sub-Saharan Africa (SSA). The importance of finance to firms is documented by Beck and Demirguc-Kunt (2006) who asserts that financial inclusion helps alleviate MSMEs growth constraints and increases their access to external finance, thus leveling the playing field between firms of different sizes.

In addition, enterprise growth is hindered by non-financial constraint of a regulatory nature. For instance, Djankov, La Porta, Lopez-De-Silanes, and Shleifer (2002) find that sub-Saharan countries tend to have heavier regulation of entry due to higher

\footnotetext{
${ }^{1}$ The term firms and enterprises are used interchangeably in this paper
}

(c) The Author(s). 2019 Open Access This article is distributed under the terms of the Creative Commons Attribution 4.0 International License (http://creativecommons.org/licenses/by/4.0/), which permits unrestricted use, distribution, and reproduction in any medium, provided you give appropriate credit to the original author(s) and the source, provide a link to the Creative Commons license, and indicate if changes were made. 
corruption, informality, and poor infrastructure. However, this phenomena is not unique to sub-Saharan countries. Klapper, Laeven, and Rajan (2004) find that costly regulations constrain the entry of new enterprises in Europe, especially in sectors that should normally have high entry. Regulatory barriers force enterprises to be larger and cause incumbent firms in naturally high-entry industries to grow more slowly.

In Uganda, MSMEs contribute close to $90 \%$ of private sector production and play a crucial role in income generation, especially for the poor (UIA, 2008). Yet, enterprises are largely informal focused on low productivity activities. Entrepreneurship in Uganda is largely a by-product of poverty and a lack of accessible formal employment (World Bank, 2017). Enterprises in Uganda are largely micro: according to GoU (2014), more than 50\% of the firms in Uganda employ five or less people. Importantly, 69\% of firms in Uganda generate UGX10 million or less in annual turnover. Indeed, only $10 \%$ of firms have a bank loan or line of credit. Adverse business environment have been blamed for low rate of survival of firms in Uganda (World Bank, 2014a). ${ }^{2}$ Indeed, Turyahikayo (2015) finds the cost and reliability of electricity as a major constraint to doing business in Uganda. Egesa (2010) confirms correlation between technological uptake and a high failure rate of firms in Uganda. Buyinza (2011) finds that integration of East Africa has adversely affected the survival of Ugandan firms. Nevertheless, firms with the ability to export, especially to the advanced markets, have a higher chance of survival compared to the non-exporting ones.

Given this background, the first objective of this paper is to assess whether there are differences in growth across firms of different size when exposed to financial inclusion and other factors affecting the business environment such as regulatory environment, corruption, and access to infrastructure. Differential effects across firms of different size can stem from the fact that there can be differences in the underlying objective conditions faced by firms. Thus, it could be that the same extent of financial inclusion is more beneficial to smaller firms or that the same extent of power outages is less damaging to larger firms because they have access to generators. The second objective is to test the hypothesis that financial inclusion and its impacts on firm growth are dependent on the interplay between financing and other investment climate factors. A poor business environment raises cost and risk associated with doing business thus diminishing the impact of finance. In this regard, the extent of corruption, the state of infrastructure, property rights, enforcement of business regulations, and the overall openness in the management of public resources can affect the impact of finance on firms' growth (World Bank, 2004).

Unlike most existing studies, which rely on macro level data, this paper exploits firm level data on finance and business environment conditions. Firm level data allows the paper to interrogate whether the impact of the business environment is unbiased across firm size. Most importantly, this paper mitigates the risk of the potential measurement error, omitted variable bias, and endogeneity. First, we utilize a full set of sector-survey interaction dummies to deal with measurement error. Second, and in addition to financial inclusion, we include other dimensions of the broader business environment to concurrently deal with concerns of omitted variable bias. Last, we use location-sectorsize averages less individual firms' own responses of the business environment measures to tackle endogeneity.

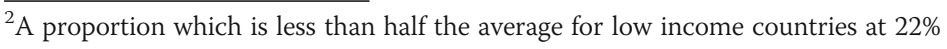


The rest of the paper is structured as follows. "Literature review" section lays out the literature review. "Methods and data" section describes the methods and the data. "Results and discussion" section presents the results. "Conclusion" section concludes.

\section{Literature review}

Micro, small, and medium enterprises (MSMEs) are an important generator of jobs. Hence, insights into the determinants of enterprise growth are important from a policy perspective. There is a growing literature that assesses the effects of the set of factors, policies, and institutions that affect enterprise growth. Generally, the determinants of enterprise growth are characterized as either being external or internal to the firm. Most studies summarize and classify the determinants of enterprise growth into three broad dimensions: individual, organizational, and investment climate factors (Zhou \& de Wit, 2009).

At the individual level, entrepreneurship has gained momentum as a key vehicle leading to higher jobs and sustainable economic growth. However, entrepreneurs in sub-Sahara Africa face many challenges among them lack of financial inclusion, the tightest laws and regulations, and the poorest infrastructure (Legas, 2015). Lack of a comprehensive entrepreneurial training and small market size also emerged as a critical challenge that entrepreneurs in the region face (Dugassa, 2012).

At the organizational level, there is substantial evidence that small enterprises face larger growth constraints and have less access to formal sources of external finance (Beck \& Demirguc-Kunt, 2006). The international literature mentions that MSMEs depend heavily on internal finance due to lack of transparency (Berger \& Udell, 1998), lack of trading history (Cassar, 2004), and high risk of failure (Huyghebaert \& Van de Gucht, 2007), among other constraints. In Uganda, the endogeneity of access to finance varying across firms has been well documented in Ishengoma and Kappel (2008), Kasekende and Opondo (2003), and Obwona and Mugume (2001).

Lack of finance hinders not only the creation of new MSMEs but also constrains the growth of existing MSMEs. Consequently, low access to finance explains (in part) why job creation in sub-Saharan Africa (SSA) is concentrated in the micro/informal firms with low productivity (Olawale \& Garwe, 2010). Weakness of MSMEs is more often manifested in form of lack of collateral (Galindo \& Micco, 2005), whereby lack of collateral necessitates financial institutions to limit the amount of credit allocated to MSMEs relative to other sectors (Beck, Demirguc-Kunt, \& Levine, 2003). It is in this regard that this paper differentiates the impact of finance across size classes of firms.

However, many MSMEs desire to remain small, which is a rationalization of their lack of capability, and finance is not of crucial importance (O'Farrell, 1986). In this case, policy instruments designed to aid the process of growth in small businesses are likely to have little or no impact upon such firms.

At the institutional level, the limited access to finance and constrained enterprise growth is partly due to the investment climate. This is particularly true in lower income countries and those with higher levels of corruption (Hallward-Driemeier \& Aterido, 2007). Certainly, financing is more scarce and expensive in countries with weak enforcement and weak institutions (Galindo \& Micco, 2007). Market and institutional failures and informality of MSMEs deny them access to financial services (Kasekende \& Opondo, 2003). Institutional and business environment failures bias finance toward larger firms (Aterido et al., 2009). However, the bias in financial inclusion decreases in 
choice of sector and location (Lakuma, Marty, \& Kuteesa, 2016), age (Cabral \& Mata, 2003), reduced informality, and infrastructure (Turyahikayo, 2015) (see Fig. 1). As such, the subject of choice of location and sector, influence of infrastructure, and nature of governance in determining firm growth is examined more rigorously in this study.

While improving on the knowledge on financial inclusion and firm growth, the current literature suffers from three potential shortcomings that can be addressed in our study. First, financial inclusion is a broad term. To track the impact of financial inclusion on firm growth in Uganda, a clear and unified definition of the concept of financial inclusion is needed to identify policy gaps, understand both served and underserved firms, and define priorities for action. The World Bank (2014) defines financial inclusion as the state of an individuals and businesses having access to useful and affordable financial products and services that meet their needs. Access to financial services is critical in Uganda where 46\% of the population is excluded from financial services (EPRC, 2013).

Second, studies need to determine the appropriate indicator to effectively capture firm growth in face of data limitation. Shepherd and Wiklund (2009) suggest including either of the following: sales levels, profitability, number of employees, and market. Many studies use sales growth as a measure of firm growth as it translates more easily across countries and industry contexts, and also is the metric of choice for entrepreneurs (Delmar et al. 2003). However, Shepherd and Wiklund (2009) find that employment growth seems to be the metric that shows best concurrent validity. Therefore, this study retains employment growth as an indicator of firm growth.

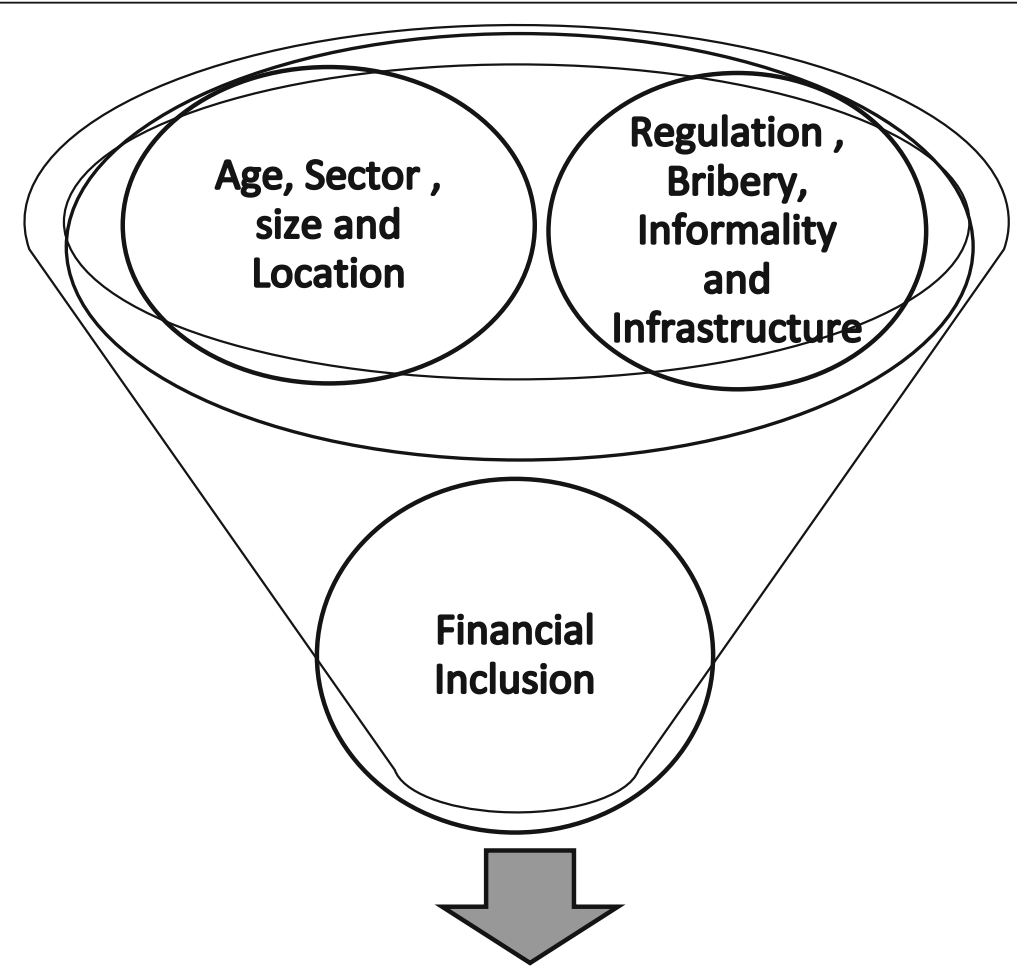

Firm Growth

Fig. 1 Factors affecting firm growth. Source: authors 
Thirdly, this study follows Aterido et al. (2009) to focus on regressions that combine multiple dimensions in a single regression to address potential bias in the estimates and to measure directly which dimensions have the largest impact on firm performance. This paper measures whether there are significant differences in the impact of finance and the business environment across firm types, especially by firm size (see Fig. 1). This paper also spends a substantial amount of time in reducing endogeneity between financial inclusion/investment climate measures and business performance.

\section{Methods and data}

Following Aterido et al. (2009) and Restuccia and Rogerson (2008), this paper draws on data from Uganda's 2013 World Bank Enterprise Survey (WBES), which comprises data on 762 firms across Uganda. The WBES methodology is described in World Bank (2009). ${ }^{3}$ The WBES data provides information on firm performance as well as the investment and business environment faced by firms. The data contains information on firms spanning a range of sectors: $50 \%$ of firms are in the manufacturing sector, $22 \%$ are in retail, and $28 \%$ are in other sectors (including hotel and restaurant businesses, IT services, and wholesale providers).

The sample contains a range of firm sizes. We examine firm size using the number of permanent employees. We categorize firms according to Uganda's definition of firm sizes: micro (1-4 employees), small (5-19 employees), medium (20-99 employees), and large (100 or more employees). According to these definitions, the dataset contains 46 micro firms, 461 small firms, 183 medium firms, and 50 large firms.

We measure firm performance as employment growth between 2010 and 2013. We calculate a growth rate, specifically the change in employment derived as the average employment in the two periods. Table 1 summarizes employment growth, where firm size is based on the firm's size in 2010. On average, firms experienced a 5.2\% growth. Small firms (1-4 employees) experienced the largest growth rate, of $21 \%$. Both small (5-19 employees) and large (more than 99 employees) firms experience small but positive growth on average, of about $1.6 \%$. On the other hand, a number of large firms experienced negative growth. Twenty-five percent of large firms experienced a $1.2 \%$ or smaller decrease in employees. Medium size firms (20-99 employees) experienced a 4.7\% reduction in employees, on average.

We examine the impact of finance and a number of investment climate variables on firm growth, as well as how firm characteristics are associated with finance and other investment climate conditions (see Table 2 for summaries of key variables). Nine investment climate variables are used relating to access to finance, business regulatory conditions, and corruption.

Three variables are used to measure access to finance: the share of investments financed externally (sh-invest-fin), the share of working capital financed externally (shwork-cap-fin), and the percentage of sales sold on credit (sh-sales-cr). The data reports moderate levels of access of finance: $23 \%$ of investments are financed externally, $24 \%$ of working capital is financed externally, and $22 \%$ of sales are sold on credit.

Two variables are used to measure business regulatory conditions: the percent of time managers devote to dealing with authorities (mng-time) and the number of days firms devoted to inspections during the previous year (days-inspections). On average, managers devoted $6.4 \%$ of their time to dealing with regulations and firms spent an average of 2.5 days on inspections.

${ }^{3}$ Please follow the link below for a description of the WBES Methodology: http://www.enterprisesurveys.org/ methodology 
Table 1 Employment Growth

\begin{tabular}{lllll}
\hline Initial size (2010) & Mean & 25th percentile & Median & 75th percentile \\
\hline Size 1-4 & 0.212 & 0.000 & 0.111 & 0.400 \\
Size 5-19 & 0.016 & 0.000 & 0.000 & 0.000 \\
Size 20-99 & -0.047 & -0.063 & 0.000 & 0.063 \\
Size +99 & 0.016 & -0.012 & 0.000 & 0.005 \\
Total & 0.052 & 0.000 & 0.000 & 0.118 \\
\hline
\end{tabular}

Source: Authors calculation from WBES (2013)

Growth measured as the change in employees from 2010 to 2013 divided by the average number employees in 2010 and 2013

Extent of corruption is measured as either a binary variable indicating whether the firm has had to pay a bribe to get things done (bribe $y$ - $n$ ) or a variable indicating the percent of transactions where a gift or payment was requested (bribe \%). To avoid misreporting bribe information, the survey asks about the amount paid in bribes by firms "similar to yours" rather than the firm directly. On average, $24 \%$ of firms reported giving a bribe to get things done and $0.06 \%$ of public transactions requiring a gift or informal payment. Infrastructure barriers are measured as the number of power outages firms experienced in the last year (days no power) and the percentage of cargo value that was lost in transit (loss transit). The data reveal significant infrastructure challenges; on averages, firms experienced 142 power outages over a year and 5.3\% of cargo value was lost in transit.

\section{Impact of finance and investment climate conditions on firm growth}

After examining the determinants of finance and investment climate conditions, we turn to examining the impact of investment climate conditions on firm growth. Equation 1 describes the model.

$$
\begin{aligned}
& \text { Empg }_{i}=\beta_{0}+\beta_{1} \text { Small }_{i}+\beta_{2} \text { Medium }_{i}+\beta_{3} \text { Large }_{i}+\sum_{k} \beta_{4 k} I C_{i, k} \\
& +\sum_{k} \beta_{5 k} \operatorname{Small}_{i} \times I C_{i, k}+\sum_{k} \beta_{6 k} \text { Medium }_{i} \times I C_{i, k}+\sum_{k} \beta_{7 k} \text { Large }_{i} \\
& \times I C_{i, k}+\beta_{8} \text { Foreign }_{i}+\beta_{9} \text { Government }_{i}+\beta_{10} \text { Exporter }_{i}+\beta_{11} \text { Mature } \\
& +\beta_{12} \text { Older }+\beta_{13} \text { Smallcity }+\beta_{14} \text { Empg cell }+\lambda+\epsilon_{i}
\end{aligned}
$$

Table 2 Variable descriptions

\begin{tabular}{llll}
\hline Variable & Description & Mean & SD \\
\hline Emp-gr & Employment growth & 0.05 & 0.40 \\
Labor, t & Number of employees in period t (log) & 44.07 & 238.06 \\
Sh-invest-fin & Share of investments financed externally & 22.85 & 32.41 \\
Sh-work-cap-fin & Share of working capital financed externally & 24.06 & 30.67 \\
Sh-sales-cr & Percentage of sales sold on credit & 21.59 & 24.91 \\
Mng-time & \% of management's time dealing with regulations & 6.38 & 12.69 \\
Days-inspections & Total days spent on inspections during last year & 2.46 & 3.14 \\
Bribe y-n & Bribes given to get things done (Yes-no) & 0.24 & 0.43 \\
Bribe \% & \% of public transactions where a gift or informal payment was requested & 0.06 & 0.12 \\
Days no power & Number of power outages experienced during the last year & 142.63 & 286.98 \\
Loss_transit (\%) & Percentage of the average cargo's value lost while in transit & 5.28 & 19.96 \\
\hline
\end{tabular}

Source: authors calculation from WBES (2013) 
Empg refers to the rate of growth in permanent employees from 2010 to 2013. We use financial inclusion and three other $(k)$ categories of investment climate (IC) variables: regulation, corruption, and infrastructure. We interact financial inclusion and investment climate variables with firm size to understand how the impact of financial inclusion and investment climate on employment growth varies across firm size. In addition, we include a number of controls that may also be associated with employment growth. Controls include whether the firm has significant foreign ownership, government ownership, significant exports, firm age (using Mature and Older dummies), and whether the firm resides in a city with less than 1 million inhabitants. To control for differences across firm sectors, we include a set of sector dummies $(\lambda)$.

A problem in estimating the impact of financial inclusion and investment climate on employment growth is endogeneity: this is where financial inclusion and investment climate conditions are likely to be endogenous to firm performance. To account for endogeneity, we construct a measure of financial inclusion and investment climate conditions that reflect conditions faced by firms similar to firm $i$, rather than using firm $i$ 's individual response. Specifically, financial inclusion and investment climate variable for firm $i$ reflects the average response of firms in the same location-sector-size category, where location refers to whether the firm resides in a small city, sector refers to the firm's primary sector, and size refers to whether the firm is a micro, small, medium, or large sized firm. When taking averages, we exclude firm i's responses.

When matching average location-sector-size values to firms, we make a distinction between current and past conditions, specifically in regard to the firm size. Our procedure involves two steps. First, we calculate a firm's average size across 2010 and 2013 to construct the location-sector-size averages. Second, we match the average indicators to firms based on their initial-not current-size. The first step-using average firm size across time periods-helps account for firms that recently changed size and may face financial inclusion and investment climate conditions that are different from firms that have remained in a size category for a longer period of time. The second step-matching averages to initial conditions-allows use of conditions faced by firms of a certain size in 2013 as a measure for conditions of firms of that size in 2010. For example, we use information on conditions faced by micro firms in 2013 as a measure for conditions faced by micro firms in 2010. Doing so helps to mitigate against endogeneity concerns. This procedure assumes that financial inclusion and investment climate conditions remain similar over time for location-sector-size categories of firms, rather than for firms themselves.

A remaining concern is that results may capture the effects of shocks that are correlated across firms, which are correlated with both average financial inclusion and investment climate conditions and firm growth. To reduce this potential bias, we include the average employment growth of the size-sector-location cell used to compute financial inclusion and investment climate conditions as a control variable (empg cell).

Table 3 reports results of examining the determinants of the nine IC variables. Regarding access to finance, estimates indicate that controlling for firm characteristics and sector interaction dummies, there are no differences in access to finance, measured as working capital financed externally and as a share of sales on credit between MSMEs. However, there are differences in access to finance measured as share of investment between micro firms and firms of larger sizes (small and medium). 


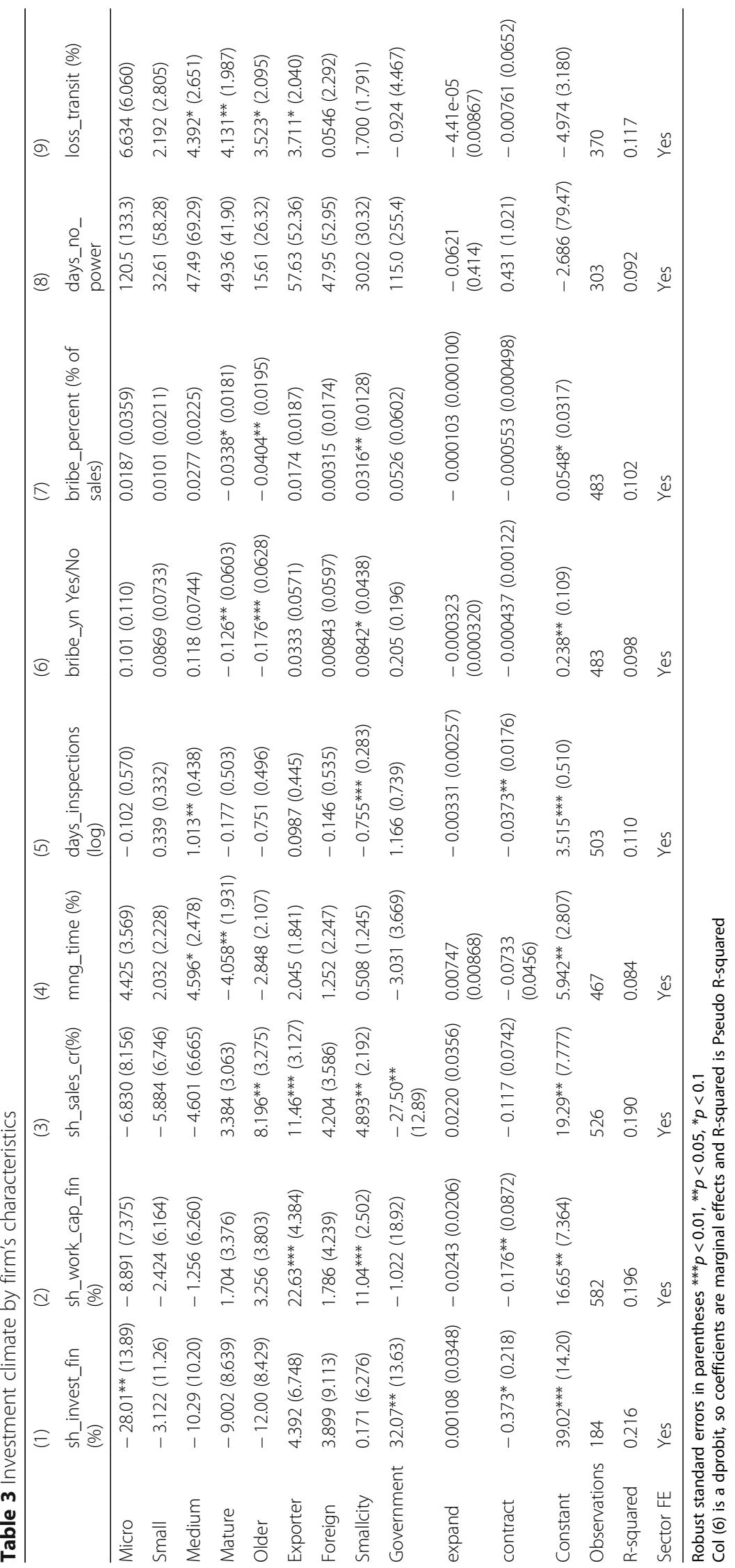


The specifications reported on Table 3 also provide important results regarding finance. Particularly, firms that contracted in the period before the survey report low access to external financing and spending less time dealing with officials relative to firms that were stable in size, which may suggest some degree of informality. Older firms have more access to finance (sales credit). Exporters and firms in small towns (Lira, Mbarara, Jinja, Wakiso, and Mukono) tend to need more finance (working capital and sales credit) than their counterpart in Kampala does. Government-owned firms prefer to use more of investment finance than working capital and sales credit to finance their activities.

Regarding business regulations, micro and small firms report a smaller share of management time devoted to dealing with government regulations than medium firms do. Days of inspections also increase monotonically with medium firms spending more days dealing with regulation than other firm sizes. Regarding corruption, there are no differences in the incidence of bribes across all firms. The payment of bribes could be correlated with the low degree of compliance with regulations and firms have to pay officials to maintain this position. For infrastructure, firm size is not correlated with the frequency of power outages. Accessing reliable power is correlated with the substantial fixed costs of owning and operating a generator, which affect all MSMEs relative to large firms. Meanwhile, losses in transit are largest among medium size firms.

\section{Variations in objective financial inclusion and investment climate conditions by firms}

We first examine how financial inclusion and investment climate variables are associated with firm characteristics. Specifically, we regress financial inclusion and investment climate variable against a number of firm-level characteristics, estimating separate models for each investment climate variables. Equation 2 describes the model.

$$
\begin{aligned}
& \text { ICvariable }_{i}=\beta_{0}+\beta_{1} \text { Small }_{i}+\beta_{2} \text { Meduim }_{i}+\beta_{3} \text { Large }_{i}+\beta_{4} \text { Foreign }_{i}+ \\
& \beta_{5} \text { Exporter }_{i}+\beta_{6} \text { Mature }_{i}+\beta_{7} \text { Older }_{i}+\beta_{9} \text { Government }_{i}+\beta_{10} \text { Smallcity }_{i}+ \\
& \beta_{11} \text { Expand }_{i}+\beta_{11} \text { Contract }_{i}+\lambda+\epsilon_{i}
\end{aligned}
$$

Small, Medium, and Large are binary variables indicating the size category of firm $i$, where micro firms are the excluded category. Foreign is a binary variable indicating whether private foreign individuals or organizations own $10 \%$ or more of the firm. Exporter is a binary variable indicating whether $10 \%$ or more of the firms' sales are exported. Mature and Older are age categories, where Mature indicates a firm existing for 6-15 years, and older for more than 15 years; Young-a firm age of less than 6 years-is the excluded variable. Government is a binary variable indicating whether the government/state owns $10 \%$ or more of the firm. Smallcity indicates whether the firm resides in a city with fewer than 1 million inhabitants. Expand and contract measure the rate of employment expansion or contraction from 2010 to 2013; here, the omitted variable is whether employment remained unchanged. $\lambda$ represents firm sector dummies.

\section{Results and discussion}

Table 4, column (1) reports the effects of financial constraints and unfavorable business environment across firm sizes. Results suggest that lack of finance and a weak business environment tends to hurt the growth of micro, small, and medium firms, and benefits the growth of large firms. Columns (2) to (5) address endogeneity of respondents. As expected, the 
coefficients on firm size categories indicate that firm growth declines monotonically with firm size. The paper shows that the use of endogenous variables to measure the effects of finance on firm growth are only significant on medium-sized firms due to downward bias.

\section{Finance}

Table 4 column (1) also test the hypothesis by Beck et al. (2003) and Demirgüç-Kunt and Maksimovic (1998) whether the same amount of financing (measured as percentage of investment financed externally), would be the same across different firm sizes in Uganda. Finance is defined such that a larger number implies better access to finance. The results show that access to finance boost MSMEs growth relative to large firms.

The paper also investigates the sensitivity of these results to different ways of estimating the IC measures. Using firms' individual responses (Table 4 column 2), we find that access to finance has a negative effect on medium-sized firms but no effect on firms of other sizes. ${ }^{4}$ This suggests that using endogenous measures may underestimate the effect of finance on micro and small firms. Column (3) reports the result of reproducing the estimates presented in column (1) for the same sample as in column (2), where the results are similar. Overall, the results show that finance helps firms, in Uganda, grow if endogeneity is properly controlled.

Column (4) reports the results when using investment climate (IC) measures constructed as described in the data section, but with the only difference that the averages within city, sector, and size cells are matched to current rather than initial size. As mentioned earlier, this is likely to re-introduce some level of endogeneity as growing firms are matched with higher levels of access to finance. In this case, we find that all firms benefit from access to finance. However, the coefficients point to smaller benefits for medium firms and the differences across firm size are statistically significant.

Column (5) presents the results of further assessing the robustness of our main results when constructing the IC averages with sector-location averages. ${ }^{5}$ The results are negative for MSMEs relative to large firms. The question is why would access to finance constrain firm growth? It is possible that access to finance may not be a binding constraint to MSME in Uganda. Indeed, World Bank (2017) suggests that entrepreneurship in Uganda may be as result of poverty and lack of wage employment and not because of talent. This evidence may also point that location and sector of operation may be of importance while considering the effects of financial access on MSMEs growth. This result supports the argument against restricting financing to certain sectors and locations because when firms are financially restricted they are also likely to be size constrained. It should be noted, however, that these results are insignificant.

\section{Other investment climate factors}

Measures of the regulatory environment show that business regulations measured as the share of time that management devotes to dealing with government regulations are significant for larger firms than the micro, small, and medium firms. This is likely because MSMEs are informal, and are not visible to the authorities, unlike their large counterparts (Tybout, 2000). It is also possible that MSMEs pay a bribe to remain invisible and

\footnotetext{
${ }^{4}$ The number of observations in column 2 are fewer because not all firms report information for endogenous variables

${ }^{5}$ Sectors are Food, Textiles and garments, other manufacturing, Retail and Other services. On the other hand, locations are Kampala, Mbarara, Jinja, Mbale, Wakiso, and Lira.
} 
Table 4 Impact of finance and other investment climate on employment growth

\begin{tabular}{|c|c|c|c|c|c|}
\hline & (1) & (2) & (3) & (4) & (5) \\
\hline & $\begin{array}{l}\text { IC var. cell avg.: } \\
\text { matched to } \\
\text { initial size }\end{array}$ & $\begin{array}{l}\text { Individual } \\
\text { firm response }\end{array}$ & $\begin{array}{l}\text { ICvar as in } \\
\text { Col. } 1 \text { with } \\
\text { Col } 2 \text { sample }\end{array}$ & $\begin{array}{l}\text { ICvar avg.: } \\
\text { matched to } \\
\text { current size }\end{array}$ & $\begin{array}{l}\text { ICvar cell avg:: } \\
\text { sector-location }\end{array}$ \\
\hline Sh_invest_fin & $\begin{array}{l}-0.0425^{* * *} \\
(0.0125)\end{array}$ & $\begin{array}{l}0.0108 \\
(0.00981)\end{array}$ & $\begin{array}{l}-0.0845^{* *} \\
(0.0321)\end{array}$ & $\begin{array}{l}-0.0110 \\
(0.00852)\end{array}$ & $\begin{array}{l}0.0942^{* * *} \\
(0.0326)\end{array}$ \\
\hline (Micro)*Sh_invest_fin & $\begin{array}{l}0.0461^{* * *} \\
(0.0138)\end{array}$ & $\begin{array}{l}-0.0101 \\
(0.0125)\end{array}$ & $\begin{array}{l}0.211^{* * *} \\
(0.0637)\end{array}$ & $0.0295^{* *}(0.0109)$ & $-0.0187(0.0343)$ \\
\hline (Small)*Sh_invest_fin & $\begin{array}{l}0.0499^{* * *} \\
(0.0139)\end{array}$ & $\begin{array}{l}-0.0110 \\
(0.00980)\end{array}$ & $0.0112(0.0323)$ & $\begin{array}{l}0.0256^{* *} \\
(0.00911)\end{array}$ & $\begin{array}{l}-0.00993 \\
(0.0299)\end{array}$ \\
\hline $\begin{array}{l}\text { (Medium)*Sh_invest_ } \\
\text { fin }\end{array}$ & $\begin{array}{l}0.0770^{* * *} \\
(0.0164)\end{array}$ & $\begin{array}{l}-0.0176^{*} \\
(0.00892)\end{array}$ & $\begin{array}{l}0.0878^{* *} \\
(0.0331)\end{array}$ & $0.0246^{*}(0.0122)$ & $-0.0176(0.0346)$ \\
\hline mng_time & $\begin{array}{l}0.000169 \\
(0.0476)\end{array}$ & $\begin{array}{l}-0.00785 \\
(0.00529)\end{array}$ & $\begin{array}{l}-0.126 \\
(0.0844)\end{array}$ & $\begin{array}{l}-0.203^{* * *} \\
(0.0452)\end{array}$ & $0.128(0.247)$ \\
\hline$($ Micro)*mng_time & $0.00244(0.0469)$ & $\begin{array}{l}-0.0165 \\
(0.261)\end{array}$ & $0.757^{* * *}(0.217)$ & $0.209^{* * *}(0.0565)$ & $0.564^{*}(0.321)$ \\
\hline$($ Small)*mng_time & $\begin{array}{l}0.000421 \\
(0.0553)\end{array}$ & $\begin{array}{l}0.0129 \\
(0.00972)\end{array}$ & $\begin{array}{l}0.190^{* *} \\
(0.0876)\end{array}$ & $0.235^{* * *}(0.0447)$ & $0.105(0.210)$ \\
\hline (Medium)*mng_time & $0.00852(0.0526)$ & $\begin{array}{l}0.00846 \\
(0.00568)\end{array}$ & $0.108(0.0836)$ & $0.222^{* * *}(0.0448)$ & $0.0195(0.239)$ \\
\hline bribe_yn & $1.061(2.033)$ & $-1.344(0.930)$ & $\begin{array}{l}-29.92^{* * *} \\
(5.013)\end{array}$ & $7.862^{* * *}(1.541)$ & $7.141(4.983)$ \\
\hline$($ Micro)*bribe_yn & $-0.887(2.100)$ & $-0.730 *(0.362)$ & $\begin{array}{l}-39.08^{* *} \\
(14.86)\end{array}$ & $\begin{array}{l}-8.697^{* * *} \\
(1.707)\end{array}$ & $-8.391(5.885)$ \\
\hline (Small)*bribe_yn & $-1.506(2.336)$ & $-0.276(0.168)$ & $37.29 * * *(5.257)$ & $\begin{array}{l}-8.766^{* * *} \\
(1.559)\end{array}$ & $0.468(5.283)$ \\
\hline (Medium)*bribe_yn & $-3.984(2.852)$ & $-0.156(0.182)$ & $30.74^{* * *}(5.720)$ & $\begin{array}{l}-9.674^{* * *} \\
(1.934)\end{array}$ & $2.004(5.644)$ \\
\hline days_no_power & $\begin{array}{l}0.0133^{* * *} \\
(0.00255)\end{array}$ & $\begin{array}{l}-0.00180 \\
(0.00183)\end{array}$ & $\begin{array}{l}-0.00659 \\
(0.00705)\end{array}$ & $\begin{array}{l}-0.00701^{* *} \\
(0.00264)\end{array}$ & $\begin{array}{l}-0.0380^{* * *} \\
(0.00663)\end{array}$ \\
\hline $\begin{array}{l}(\text { Micro)*days_no_ } \\
\text { power }\end{array}$ & $\begin{array}{l}-0.0133^{* * *} \\
(0.00256)\end{array}$ & & & $\begin{array}{l}0.00703^{* *} \\
(0.00273)\end{array}$ & $0.0207^{*}(0.0111)$ \\
\hline $\begin{array}{l}(\text { Small)*days_no_ } \\
\text { power }\end{array}$ & $\begin{array}{l}-0.0141^{* * *} \\
(0.00249)\end{array}$ & $\begin{array}{l}0.00175 \\
(0.00183)\end{array}$ & $\begin{array}{l}0.0101 \\
(0.00696)\end{array}$ & $\begin{array}{l}0.00597^{*} \\
(0.00318)\end{array}$ & $\begin{array}{l}0.00278 \\
(0.00586)\end{array}$ \\
\hline $\begin{array}{l}(\text { Medium)*days_no_ } \\
\text { power }\end{array}$ & $\begin{array}{l}-0.0186^{* * *} \\
(0.00210)\end{array}$ & $\begin{array}{l}0.00130 \\
(0.00218)\end{array}$ & $\begin{array}{l}0.0105 \\
(0.00682)\end{array}$ & $\begin{array}{l}0.00839^{* *} \\
(0.00310)\end{array}$ & $\begin{array}{l}0.00150 \\
(0.00640)\end{array}$ \\
\hline (Micro) & $0.811(0.700)$ & & & $-1.475^{* *}(0.534)$ & $-4.210^{*}(2.151)$ \\
\hline (Small) & $0.594(0.689)$ & $\begin{array}{l}-1.016^{* * *} \\
(0.295)\end{array}$ & $\begin{array}{l}-12.01^{* * *} \\
(2.515)\end{array}$ & $\begin{array}{l}-1.810^{* * *} \\
(0.533)\end{array}$ & $-1.122(1.235)$ \\
\hline (Medium) & $0.823(0.894)$ & $\begin{array}{l}-0.792^{* *} \\
(0.299)\end{array}$ & $\begin{array}{l}-11.95^{* * *} \\
(2.568)\end{array}$ & $\begin{array}{l}-1.933^{* * *} \\
(0.615)\end{array}$ & $-0.601(1.419)$ \\
\hline Constant & $0.743(0.765)$ & $1.470^{* *}(0.604)$ & $11.44^{* * *}(2.467)$ & $2.571^{* * *}(0.507)$ & $8.528^{* * *}(1.584)$ \\
\hline Observations & 608 & 97 & 96 & 602 & 613 \\
\hline R-squared & 0.468 & 0.650 & 0.902 & 0.456 & 0.789 \\
\hline Firm Controls & Yes & Yes & Yes & Yes & Yes \\
\hline Sector FE & Yes & Yes & Yes & Yes & Yes \\
\hline
\end{tabular}

Standard errors clustered on location-sector-size; ${ }^{* *} p<0.01,{ }^{* *} p<0.05,{ }^{*} p<0.1$

informal. Particularly, business regulations do not appear to impact the growth of micro firms. The positive effect for micro firms suggest that micro firms benefit from a generally lower enforcement, which may help divert some economic activity to micro firms. Consequently, it is not surprising that corruption (paying a bribe) is much more of a problem to micro firms than other firm sizes. Micro firms may have to pay a bribe to remain invisible 
(ibid). These results are quite similar across all specifications regardless of how the IC variables are computed, suggesting that endogeneity is less important in these two cases.

Concerning infrastructure bottlenecks, measured as the incidence of power outages, the study finds evidence that infrastructure bottlenecks tend to stunt the growth MSMEs. However, these results depend on the degree to which we account for endogeneity. In Table 4 column 4, we find that MSMEs instead may benefit from the troubles of larger, possibly more productive firms, as some production may be diverted to micro firms. This is consistent with MSMEs using less capital and energy-intensive modes of production, whereby benefits that these processes provide can be sustained due to hardships hitting the large firms. These results appear stronger in column 5. However, Adewuyi and Emmanuel (2018) find that power outages undermine firm growth in Nigeria regardless of firm size. This calls for a deeper interrogation of these results.

\section{Robustness}

In this section, the paper examines whether our results are robust to changes in the definition of variables and set of controls.

\section{Addressing other possible sources of endogeneity}

The paper addresses potential source of endogeneity emanating from choice of locations based on availability of finance and the quality of the business environment. Table 6 column (1) in the Appendix reports the results if we restrict the sample to domestic-owned MSMEs who tend not to have many options on the choice of location and as such location tends to be associated with the place of birth or residence of the business owner. ${ }^{6}$ The results are insignificant, nevertheless.

\section{Alternative definitions of access to finance}

The second set of robustness checks involves using alternative measures of access to finance. There are two sets of results, indicating that the nature of the finance being captured matters and that the results are somewhat sensitive to whether variation across sectors is included or not. To examine the different types of finance, two additional measures are included-the share of sales made on credit and access to working capital from external institutions. Unlike the measure of finance used on Tables 3 and 4, the variables on Table 6 column 2 and 3 measure access to a more informal form of financing and to shorter term financing from institutions. In the case of the share of sales on credit, column (2) shows that MSMEs share in the benefits of access to this financing relative to large firms.

For access to working capital, Table 6 column (3) confirms the results in Table 6 column (2). It should be noted that these results are sensitive to whether one allows for sectoral variation in Uganda to be included to control for endogeneity that may affect firm performance and increase their demand for financing. The paper discerns that sectors with a larger proportion of MSMEs stand to benefit disproportionately from financial development, a result that is consistent with Beck et al. (2003).

Table 6 Column (4) also includes alternative measures for the other three investment climate measures. They are days of inspections, the size of bribes paid, and losses incurred during transportation delays. The measure of inspections and management time

${ }^{6}$ Foreign firms and large domestic firms are the most likely to be selective in their choice of location. 
spent dealing with officials do not deter MSMEs from growing. However, poor transportation infrastructure deters micro and small firms from growing.

\section{Variation in the definitions of size}

Table 7 reports results using difference definitions of firm size classifications. For comparison purposes, column (1) reproduces the results of Table 4, column (1). Column (2), Table 7 excludes micro firms. The results on the effects of access to finance to firm growth are consistent with results on Table 4, which lend credence to the assertion that the level of productivity in firms in Uganda tend to be uniform and benefits accruing from financial access tend to spread across MSMEs firms relative to large firms. Column 3 follows the UIA (2008) definition of firms. The results on the effect of finance are insignificant. The results on corruption are only significant in the UIA (2008) definition, which again tend to suggest that bribes tend to aid the growth of MSMEs at the expense of large firms.

\section{Age versus size}

Firms tend to start operations when they are small and grow overtime. In this case, size is strongly correlated with age. Table 8 assesses whether differences in the impact of finance and other business environment variables could be related to age rather than size by adding a full set of interactions of age dummies with finance and IC variables to the baseline results (Table 4, column 1).

The effects of interaction between size and financial access have negative effect on growth of small firms. This lends additional support to the selection story proposed by Jeong and Townsend (2008) that asserts that small firms are the ones that are likely to be less productive, and therefore, more likely to be hurt by increasing costs of inputs driven by a higher supply of credit. This result is insignificant among micro firms because it is unlikely that firms of that size outsource credit. Relative to large firms, there is a positive and significant relationship between older MSMEs with access to finance and MSMEs growth. Age may be correlated with access to financial networks and influence channels. We may also be capturing the fact that access to finance makes the survival of certain types of firms more likely, which then are observed as older at the time of the survey. At the same time, older firms tend to benefit from regulation and suffer from corruption.

In other results, regulations tend to favor older more established firms relative to younger ones. Combined with the size interactions, these results qualify the baseline results. These results suggest that regulations aid small, medium, and older firms that have been in business for a while, rather than firms that are small and young. Similarly, these results justify the hypothesis that small and medium firms benefit from a poor regulatory environment. Another interesting result of the size interactions is that corruption seems to benefit older, smaller, and medium established firms. As earlier mentioned, age could be correlated with the access to networks and influence channels.

\section{Firm characteristics and institutional environments}

Table 5 reports results of firms in groups according to their characteristics or institutional environments. Columns (1) and (2) report results of firms indicating different reasons for not applying for a new line of credit. Column (1) reports results of the subsample of firms that did not apply for a new line of credit because they reported no 
need for a loan. While column (2) reports results of the subsample of firms that did not apply for a loan due to obstacles (e.g., application procedure was too complex, interests rates were not favorable, collateral requirements were too high, etc.). Columns (3) and (4) report results of firms indicating different opinions about the consequences of corruption; column (3) reports results of the subsample of firms that indicated corruption was not an obstacle or a minor obstacle, while column (4) reports results of the subsample of firms that indicated corruption was a moderate, major, or very severe obstacle. Columns (5) and (6) report results of firms indicating different opinions regarding the rule of law, specifically the quality of the court system. Column (5) reports results of the subsample of firms that thought the court system is fair, impartial, and uncorrupted, while column (6) reports results of the subsample of firms that did not think the court system is fair, impartial, and uncorrupted.

\section{Conclusion}

This paper provides new evidence of the role of finance and the investment climate on firm growth in Uganda. The results suggest that lack of finance and a weak business environment tends to constrain the growth of MSMEs and benefits the growth of large firms. The results also show a positive effect of increased access to finance on MSMEs growth relative to large firms. These effects are not significant, however. As such, the use of measures to evaluate the effects of finance on firm growth is only significant on medium-sized firms due to downward bias.

Measures of regulatory environment and infrastructure suggest that MSMEs benefit from informality, less regulation, and less infrastructure development, which may help divert some economic activity to MSMEs. However, MSMEs are more susceptible to giving bribes to sustain the informal and the invisible status.

We also make effort to overcome endogeneity between financial access and investment climate measures and business performance. Accounting for endogeneity reduces the magnitude of effects of financial access and investment climate measures on the performance of different types of firms. Nevertheless, financial access, particularly external finance to fund investment, facilitates the growth of Uganda's MSMEs relative to large firms.

Unlike Aterido et al. (2009), there is evidence to suggest that MSMEs in Uganda benefit more from financial access than large firms do. The paper interprets these results as evidence that MSMEs are more credit constrained. While MSMEs entrepreneurs in Uganda may not have the capability, they have the willingness to grow their firms but are constrained by lack of finance.

Another important finding is that business regulations, measured as a higher share of management time spent dealing with regulations or inspections, does not affect the growth of micro firms, relative to large firms. This is likely because micro firms pay bribes to remain invisible.

The policy implication on size, efficiency, and dynamism of the business sector in Uganda is that lack of finance displaces activity from MSMEs firms in benefit of large ones. Given that MSMEs have more employment and growth effects, there is a need to increase financial inclusion of MSMEs. There is also a need to improve the business environment, particularly formalization of micro firms. This will go a long way in increasing the capacity of the state in collecting taxes and paying for fundamental inputs for private sector development such as innovation, transport, and electricity infrastructure. 
Table 5 Institutional effects

\begin{tabular}{|c|c|c|c|c|c|c|}
\hline & (1) & (2) & (3) & (4) & (5) & (6) \\
\hline & $\begin{array}{l}\text { No need } \\
\text { for credit }\end{array}$ & $\begin{array}{l}\text { Constraints to } \\
\text { obtaining } \\
\text { credit }\end{array}$ & $\begin{array}{l}\text { Reports } \\
\text { corruption is } \\
\text { an obstacle }\end{array}$ & $\begin{array}{l}\text { Reports } \\
\text { corruption is } \\
\text { not an obstacle }\end{array}$ & $\begin{array}{l}\text { Perceives } \\
\text { court system } \\
\text { as fair }\end{array}$ & $\begin{array}{l}\text { Perceives } \\
\text { court system } \\
\text { as unfair }\end{array}$ \\
\hline Sh_invest_fin & $\begin{array}{l}-0.0535^{* * * *} \\
(0.0132)\end{array}$ & $\begin{array}{l}0.00358 \\
(0.0235)\end{array}$ & $\begin{array}{l}0.0513^{* *} \\
(0.0221)\end{array}$ & $\begin{array}{l}-0.0518^{* * *} \\
(0.0124)\end{array}$ & $\begin{array}{l}-0.0279 \\
(0.0168)\end{array}$ & $\begin{array}{l}-0.0200 \\
(0.0445)\end{array}$ \\
\hline $\begin{array}{l}\text { (Micro)*Sh_ } \\
\text { invest_fin }\end{array}$ & $\begin{array}{l}0.0831^{* * *} \\
(0.0165)\end{array}$ & $\begin{array}{l}-0.00543 \\
(0.0244)\end{array}$ & $\begin{array}{l}-0.0322 \\
(0.0210)\end{array}$ & $\begin{array}{l}0.0519^{* * *} \\
(0.0151)\end{array}$ & $\begin{array}{l}0.0368^{*} \\
(0.0179)\end{array}$ & $\begin{array}{l}0.0301 \\
(0.0458)\end{array}$ \\
\hline $\begin{array}{l}(\text { Small)*Sh_ } \\
\text { invest_fin }\end{array}$ & $\begin{array}{l}0.0597^{* * *} \\
(0.0145)\end{array}$ & $\begin{array}{l}-0.0314 \\
(0.0279)\end{array}$ & $\begin{array}{l}-0.0615^{* *} \\
(0.0264)\end{array}$ & $\begin{array}{l}0.0580^{* * *} \\
(0.0144)\end{array}$ & $\begin{array}{l}0.0321^{*} \\
(0.0179)\end{array}$ & $\begin{array}{l}0.0237 \\
(0.0450)\end{array}$ \\
\hline $\begin{array}{l}\text { (Medium)*Sh_ } \\
\text { invest_fin }\end{array}$ & $\begin{array}{l}0.0735^{* * *} \\
(0.0167)\end{array}$ & $\begin{array}{l}0.0451 \\
(0.0270)\end{array}$ & $\begin{array}{l}-0.0211 \\
(0.0247)\end{array}$ & $\begin{array}{l}0.0869 * * * \\
(0.0197)\end{array}$ & $\begin{array}{l}0.0495^{* *} \\
(0.0195)\end{array}$ & $\begin{array}{l}0.0681 \\
(0.0501)\end{array}$ \\
\hline mng_time & $\begin{array}{l}-0.0362 \\
(0.0673)\end{array}$ & $\begin{array}{l}0.394^{* * *} \\
(0.0834)\end{array}$ & $\begin{array}{l}0.0133 \\
(0.0329)\end{array}$ & $\begin{array}{l}-0.0121 \\
(0.0437)\end{array}$ & $\begin{array}{l}-0.0666 \\
(0.0395)\end{array}$ & $0.128(0.152)$ \\
\hline $\begin{array}{l}(\text { Micro)*mng_ } \\
\text { time }\end{array}$ & $\begin{array}{l}0.0412 \\
(0.0732)\end{array}$ & $\begin{array}{l}-0.328^{* * *} \\
(0.0864)\end{array}$ & $\begin{array}{l}0.00266 \\
(0.0382)\end{array}$ & $\begin{array}{l}-0.0433 \\
(0.0493)\end{array}$ & $\begin{array}{l}0.0682 \\
(0.0421)\end{array}$ & $\begin{array}{l}-0.0949 \\
(0.147)\end{array}$ \\
\hline $\begin{array}{l}(\text { Small)*mng_ } \\
\text { time }\end{array}$ & $\begin{array}{l}0.0436 \\
(0.0695)\end{array}$ & $\begin{array}{l}-0.405^{* * *} \\
(0.0849)\end{array}$ & $\begin{array}{l}-0.000709 \\
(0.0327)\end{array}$ & $\begin{array}{l}-0.0254 \\
(0.0620)\end{array}$ & $\begin{array}{l}0.0695 \\
(0.0443)\end{array}$ & $\begin{array}{l}-0.116 \\
(0.155)\end{array}$ \\
\hline $\begin{array}{l}\text { (Medium)*mng_ } \\
\text { time }\end{array}$ & $\begin{array}{l}0.0647 \\
(0.0707)\end{array}$ & $\begin{array}{l}-0.409^{* * *} \\
(0.0852)\end{array}$ & $\begin{array}{l}-0.00712 \\
(0.0389)\end{array}$ & $\begin{array}{l}0.00545 \\
(0.0543)\end{array}$ & $\begin{array}{l}0.0693 \\
(0.0508)\end{array}$ & $\begin{array}{l}-0.127 \\
(0.150)\end{array}$ \\
\hline bribe_yn & $\begin{array}{l}3.945^{* *} \\
(1.432)\end{array}$ & $7.417(5.521)$ & $\begin{array}{l}-5.328^{* * *} \\
(1.509)\end{array}$ & 0.108 (2.944) & $-2.561(4.000)$ & $\begin{array}{l}5.625^{* *} \\
(2.481)\end{array}$ \\
\hline (Micro)*bribe_yn & $\begin{array}{l}-6.277^{* * *} \\
(1.651)\end{array}$ & $\begin{array}{l}-6.215 \\
(5.532)\end{array}$ & $\begin{array}{l}5.383^{* * *} \\
(1.595)\end{array}$ & $\begin{array}{l}-0.0922 \\
(3.124)\end{array}$ & $2.037(4.518)$ & $\begin{array}{l}-5.917^{* *} \\
(2.636)\end{array}$ \\
\hline (Small)*bribe_yn & $\begin{array}{l}-4.554^{* * *} \\
(1.488)\end{array}$ & $\begin{array}{l}-4.056 \\
(5.576)\end{array}$ & $\begin{array}{l}5.877^{* *} \\
(2.168)\end{array}$ & $-0.762(3.145)$ & $2.562(4.497)$ & $\begin{array}{l}-6.370^{* *} \\
(2.539)\end{array}$ \\
\hline $\begin{array}{l}\text { (Medium)*bribe_ } \\
\text { yn }\end{array}$ & $\begin{array}{l}-4.894^{* *} \\
(2.301)\end{array}$ & $\begin{array}{l}-11.61^{*} \\
(5.580)\end{array}$ & 3.188 (1.957) & $-3.636(3.913)$ & 1.525 (5.379) & $\begin{array}{l}-9.223^{* * *} \\
(3.066)\end{array}$ \\
\hline days_no_power & $\begin{array}{l}0.0237^{* * *} \\
(0.00611)\end{array}$ & $\begin{array}{l}0.0148^{* * *} \\
(0.00355)\end{array}$ & $\begin{array}{l}-0.0206^{* *} \\
(0.00892)\end{array}$ & $\begin{array}{l}0.0125^{* * *} \\
(0.00307)\end{array}$ & $\begin{array}{l}0.00821^{* * *} \\
(0.00184)\end{array}$ & $\begin{array}{l}0.0175 \\
(0.0109)\end{array}$ \\
\hline $\begin{array}{l}(\text { Micro)*days_no_ } \\
\text { power }\end{array}$ & $\begin{array}{l}-0.0236^{* * *} \\
(0.00627)\end{array}$ & $\begin{array}{l}-0.0147^{* * *} \\
(0.00359)\end{array}$ & $\begin{array}{l}0.0167^{*} \\
(0.00907)\end{array}$ & $\begin{array}{l}-0.0114^{* * *} \\
(0.00304)\end{array}$ & $\begin{array}{l}-0.00819^{* * *} \\
(0.00185)\end{array}$ & $\begin{array}{l}-0.0178 \\
(0.0109)\end{array}$ \\
\hline $\begin{array}{l}(\text { Small)*days_no_ } \\
\text { power }\end{array}$ & $\begin{array}{l}-0.0247^{* * *} \\
(0.00610)\end{array}$ & $\begin{array}{l}-0.0141^{* * *} \\
(0.00351)\end{array}$ & $\begin{array}{l}0.0204^{* *} \\
(0.00922)\end{array}$ & $\begin{array}{l}-0.0130^{* * *} \\
(0.00315)\end{array}$ & $\begin{array}{l}-0.00889^{* * *} \\
(0.00194)\end{array}$ & $\begin{array}{l}-0.0180 \\
(0.0108)\end{array}$ \\
\hline $\begin{array}{l}\text { (Medium)*days_ } \\
\text { no_power }\end{array}$ & $\begin{array}{l}-0.0258^{* * *} \\
(0.00712)\end{array}$ & $\begin{array}{l}-0.0215^{* * *} \\
(0.00403)\end{array}$ & $\begin{array}{l}0.0151 \\
(0.00977)\end{array}$ & $\begin{array}{l}-0.0168^{* * *} \\
(0.00339)\end{array}$ & $\begin{array}{l}-0.0100^{* * *} \\
(0.00241)\end{array}$ & $\begin{array}{l}-0.0252^{* *} \\
(0.0117)\end{array}$ \\
\hline (Micro) & $\begin{array}{l}1.800^{* * *} \\
(0.612)\end{array}$ & $4.988^{*}(2.633)$ & $\begin{array}{l}-1.501 \\
(0.941)\end{array}$ & $0.0973(0.993)$ & $-0.664(1.150)$ & $\begin{array}{l}3.240^{*} \\
(1.642)\end{array}$ \\
\hline (Small) & $\begin{array}{l}1.388^{* *} \\
(0.614)\end{array}$ & $4.780 *(2.622)$ & $\begin{array}{l}-2.092^{* *} \\
(0.963)\end{array}$ & $-0.130(0.920)$ & $-1.016(1.074)$ & $\begin{array}{l}3.148^{*} \\
(1.665)\end{array}$ \\
\hline (Medium) & $0.759(0.908)$ & $\begin{array}{l}5.739^{* *} \\
(2.683)\end{array}$ & $\begin{array}{l}-2.049^{*} \\
(1.020)\end{array}$ & $0.173(1.256)$ & $-1.275(1.512)$ & $\begin{array}{l}3.590^{*} \\
(1.828)\end{array}$ \\
\hline Constant & $0.212(0.644)$ & $\begin{array}{l}-3.322^{* *} \\
(1.472)\end{array}$ & $\begin{array}{l}3.850^{* * *} \\
(0.884)\end{array}$ & $1.124(0.875)$ & $2.002^{*}(1.092)$ & $\begin{array}{l}-1.011 \\
(1.406)\end{array}$ \\
\hline Observations & 216 & 271 & 333 & 270 & 254 & 284 \\
\hline R-squared & 0.734 & 0.729 & 0.628 & 0.574 & 0.569 & 0.564 \\
\hline Firm Controls & Yes & Yes & Yes & Yes & Yes & Yes \\
\hline Sector FE & Yes & Yes & Yes & Yes & Yes & Yes \\
\hline
\end{tabular}

Standard errors clustered on location-sector-size; ${ }^{* * *} p<0.01,{ }^{* *} p<0.05,{ }^{*} p<0.1$

It should be noted, however, that this paper uses cross-sectional data and the results cannot be used to infer behavior over a period of time or determine cause and effect. Therefore, future panel surveys and availability of other data may necessitate corresponding revisions of estimated relationships. 


\section{Appendix}

Table 6 Robustness

\begin{tabular}{|c|c|c|c|c|}
\hline & (1) & (2) & (3) & (4) \\
\hline & $\begin{array}{l}\text { Sample restricted SMEs } \\
\text { domestic }\end{array}$ & $\begin{array}{l}\text { Finance }=\text { Sh- } \\
\text { sales-credit }\end{array}$ & $\begin{array}{l}\text { Finance }=\text { sh- } \\
\text { wkcap }\end{array}$ & $\begin{array}{l}\text { Four alternative IC } \\
\text { variables }\end{array}$ \\
\hline Finance & $0.00808(0.00847)$ & $-0.0216(0.0130)$ & $\begin{array}{l}-0.0351^{* * *} \\
(0.0118)\end{array}$ & $-0.0773^{* * *}(0.0184)$ \\
\hline (Micro)*Finance & $-0.00546(0.00892)$ & $0.0590^{* * *}(0.0166)$ & $\begin{array}{l}0.0597^{* * *} \\
(0.0154)\end{array}$ & $0.0912^{* * *}(0.0214)$ \\
\hline$($ Small)*Finance & $-0.00254(0.0126)$ & $0.0845^{* * *}(0.0154)$ & $\begin{array}{l}0.0728^{* * *} \\
(0.0145)\end{array}$ & $0.111^{* * *}(0.0198)$ \\
\hline (Medium)*Finance & & $0.0731^{* * *}(0.0183)$ & $\begin{array}{l}0.0737^{* * *} \\
(0.0219)\end{array}$ & $0.105^{* * *}(0.0293)$ \\
\hline Regulations & $0.00337(0.0129)$ & $-0.0199(0.0441)$ & $0.0407(0.0577)$ & $-0.815^{* * *}(0.277)$ \\
\hline$($ Micro)*Regulations & $0.00161(0.0193)$ & $0.0268(0.0443)$ & $\begin{array}{l}-0.0301 \\
(0.0575)\end{array}$ & $0.836^{* * *}(0.290)$ \\
\hline$($ Small)*Regulations & $0.00357(0.0184)$ & $0.00245(0.0468)$ & $\begin{array}{l}-0.0479 \\
(0.0626)\end{array}$ & $0.839^{* * *}(0.274)$ \\
\hline (Medium)*Regulations & & $0.0184(0.0545)$ & $\begin{array}{l}-0.0374 \\
(0.0679)\end{array}$ & $1.004^{* * *}(0.283)$ \\
\hline Corruption & $-0.756(0.963)$ & $0.685(1.974)$ & $1.681(2.000)$ & $-3.428(4.082)$ \\
\hline$\left(\right.$ Micro) ${ }^{*}$ Corruption & $0.776(1.101)$ & $0.233(2.108)$ & $-1.557(2.107)$ & $3.918(4.453)$ \\
\hline$($ Small)*Corruption & $0.114(1.258)$ & $-0.664(2.071)$ & $-2.326(2.122)$ & $0.453(4.159)$ \\
\hline$($ Medium)*Corruption & & $-0.501(2.462)$ & $-1.015(2.387)$ & $3.470(8.721)$ \\
\hline Infrastructure & $-0.000362(0.00166)$ & $0.00335(0.00331)$ & $\begin{array}{l}0.00826^{* * *} \\
(0.00200)\end{array}$ & $0.0698^{* *}(0.0326)$ \\
\hline (Micro)*Infrastructure & $0.000210(0.00165)$ & $\begin{array}{l}-0.00289 \\
(0.00340)\end{array}$ & $\begin{array}{l}-0.00731^{* * *} \\
(0.00202)\end{array}$ & $-0.0675^{*}(0.0327)$ \\
\hline$($ Small)*Infrastructure & $-0.000503(0.00194)$ & $\begin{array}{l}-0.00473 \\
(0.00338)\end{array}$ & $\begin{array}{l}-0.00837^{* * *} \\
(0.00200)\end{array}$ & $-0.0738^{*}(0.0355)$ \\
\hline (Medium)*Infrastructure & & $\begin{array}{l}-0.00571 \\
(0.00383)\end{array}$ & $\begin{array}{l}-0.00930^{* * *} \\
(0.00217)\end{array}$ & $-0.0598(0.0401)$ \\
\hline (Micro) & $0.125(0.413)$ & $-1.336(1.151)$ & $-0.114(0.856)$ & $-4.842^{* * *}(1.178)$ \\
\hline (Small) & $-0.0582(0.349)$ & $-1.688(1.086)$ & $-0.415(0.856)$ & $-5.506^{* * *}(1.075)$ \\
\hline (Medium) & & $-1.819(1.270)$ & $-1.050(1.027)$ & $-6.532^{* * *}(1.203)$ \\
\hline Constant & $1.487^{* * *}(0.440)$ & $1.404(0.887)$ & $0.786(0.783)$ & $5.234^{* * *}(0.978)$ \\
\hline Observations & 508 & 611 & 611 & 610 \\
\hline R-squared & 0.393 & 0.513 & 0.466 & 0.569 \\
\hline Firm Controls & Yes & Yes & Yes & Yes \\
\hline Sector FE & Yes & Yes & Yes & Yes \\
\hline
\end{tabular}

Dependent variable: employment growth $(E m p(t)-E m p(t-3)) /((E m p(t)+E m p(t-3)) / 2)$

Standard errors clustered on location-sector-size; ${ }^{* * *} p<0.01,{ }^{* *} p<0.05,{ }^{*} p<0.1$ 
Table 7 Other size definitions

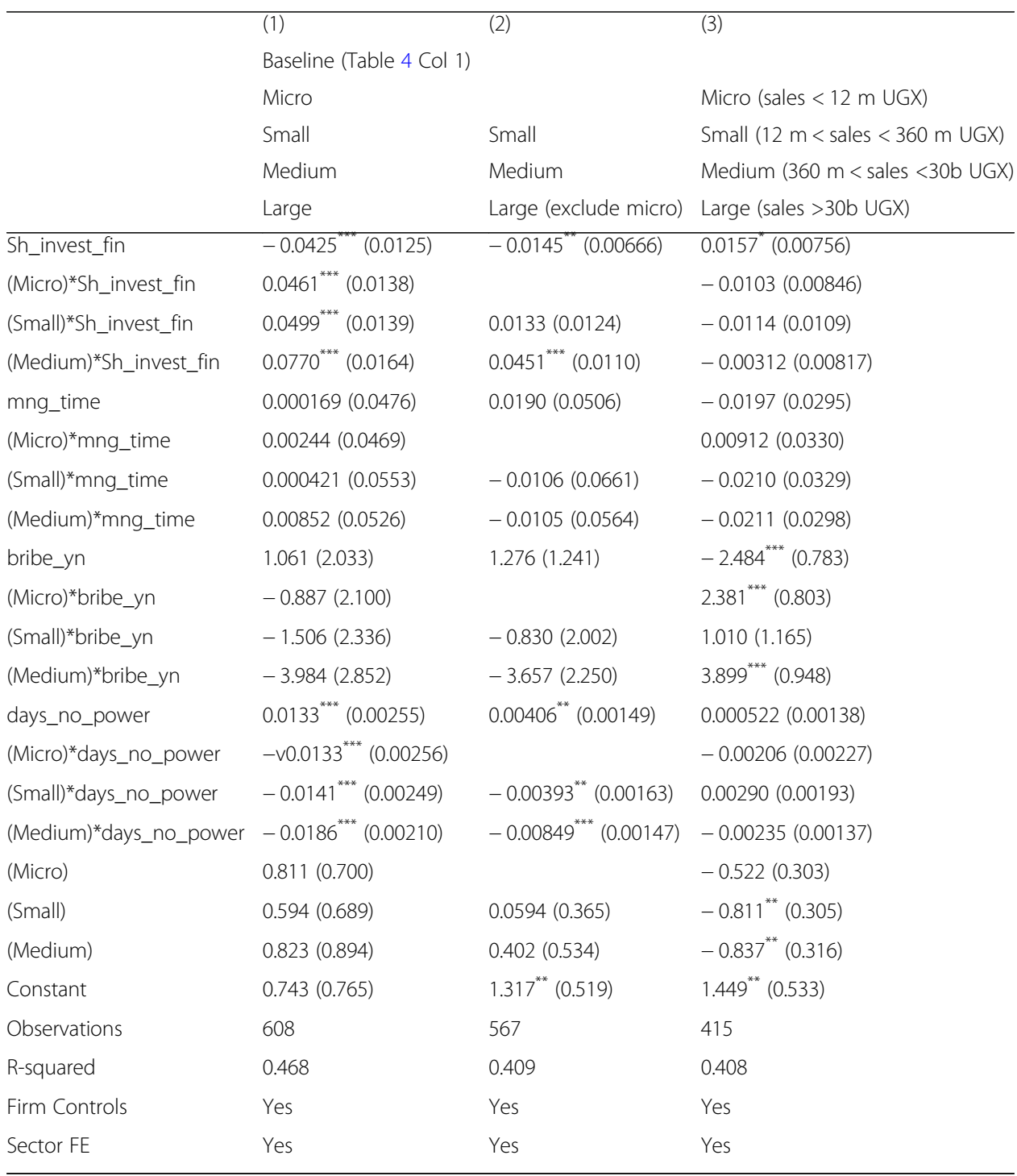

Dependent variable: employment growth $(E m p(t)-E m p(t-3)) /((E m p(t)+E m p(t-3)) / 2)$

Standard errors clustered on location-sector-size; ${ }^{* * *} p<0.01,{ }^{* *} p<0.05,{ }^{*} p<0.1$ 
Table $\mathbf{8}$ Is it size or age that matters?

\begin{tabular}{|c|c|}
\hline & (1) \\
\hline & ICvar cell avg.: matched to initial size \\
\hline Sh_invest_fin & $0.0155(0.00973)$ \\
\hline (Micro)*Sh_invest_fin & $-0.00965(0.0129)$ \\
\hline$($ Small)*Sh_invest_fin & $-0.0471^{* * *}(0.0121)$ \\
\hline (Medium)*Sh_invest_fin & $-0.0156(0.0105)$ \\
\hline mng_time & $-0.117^{* *}(0.0454)$ \\
\hline$($ Micro)*mng_time & $0.114^{* *}(0.0436)$ \\
\hline$($ Small)*mng_time & $0.0466(0.0646)$ \\
\hline (Medium)*mng_time & $0.115^{* *}(0.0458)$ \\
\hline bribe_yn & $-0.264(0.823)$ \\
\hline (Micro)*bribe_yn & $0.413(0.687)$ \\
\hline$($ Small)*bribe_yn & $5.104^{* * *}(1.397)$ \\
\hline (Medium)*bribe_yn & $2.125^{* * *}(0.728)$ \\
\hline days_no_power & $-0.00162(0.00306)$ \\
\hline$($ Micro)* days_no_power & $0.00219(0.00296)$ \\
\hline$($ Small)*days_no_power & $0.00222(0.00287)$ \\
\hline (Medium)*days_no_power & $0.000560(0.00304)$ \\
\hline (Micro) & $-0.187(0.385)$ \\
\hline (Small) & $-0.699 *(0.370)$ \\
\hline (Medium) & $-1.038^{* *}(0.420)$ \\
\hline$\left(\right.$ Mature) ${ }^{*}$ sh_invest_fin & $0.00595(0.00685)$ \\
\hline$($ Older)*sh_invest_fin & $0.00747^{*}(0.00408)$ \\
\hline$(\text { Mature) })^{*}$ mng_time & $0.00674(0.0118)$ \\
\hline$($ Older)*mng_time & $0.0200^{*}(0.0104)$ \\
\hline$($ Mature)*bribe_yn & $-0.613(0.811)$ \\
\hline$($ Older)*bribe_yn & $-0.963 *(0.551)$ \\
\hline$($ Mature)*days_no_power & $-0.000445(0.000393)$ \\
\hline$(\text { Older })^{*}$ days_no_power & $-0.000581(0.000422)$ \\
\hline (Mature) & $-0.911^{* *}(0.370)$ \\
\hline (Older) & $-0.615(0.362)$ \\
\hline Constant & $1.642^{* * *}(0.320)$ \\
\hline Observations & 608 \\
\hline R-squared & 0.451 \\
\hline Firm Controls & Yes \\
\hline Sector FE & Yes \\
\hline
\end{tabular}

Dependent variable: employment growth $(E m p(t)-E m p(t-3)) /((E m p(t)+E m p(t-3)) / 2)$

Standard errors clustered on location-sector-size; ${ }^{* * *} p<0.01,{ }^{* *} p<0.05,{ }^{*} p<0.1$ 


\section{Abbreviations}

IC: Investment climate; MSMEs: Micro, small and medium enterprises; SSA: Sub-Saharan Africa; UIA: Uganda Investment Authority; WBES: World Bank Enterprise Survey

\section{Acknowledgements}

We appreciate the World Bank for making the WBES data on Uganda publicly available.

\section{Authors' contributions}

The paper was jointly conceived, developed, and written by Mr. Lakuma, Mr. Marty, and Professor Muhumuza. All authors read and approved the final manuscript.

\section{Funding}

We received no funding to carry this research.

\section{Availability of data and materials}

We used the World Bank Enterprise Survey data for Uganda 2013 which is readily available upon request. Please note that we can also avail the do files upon request.

\section{Competing interests}

The authors declare that they have no competing interests.

\section{Author details}

${ }^{1}$ Economic Policy Research Centre, Makerere University Kampala, P.O. Box 7841, Kampala, Uganda. ${ }^{2}$ Thomas Jefferson Program in Public Policy, PO Box 8795, Williamsburg, VA 23187, USA. ${ }^{3}$ School of Economics, College of Business and Management Science, Makerere University, Kampala, Uganda.

Received: 6 November 2018 Accepted: 14 August 2019

Published online: 06 September 2019

\section{References}

Adewuyi, A. O., \& Emmanuel, Z. (2018). Electricity outages and firm performance across the six geo-political zones in Nigeria: The role of corruption. MPRA working paper series.

Aterido, R., Hallward-Driemeier, M., Pagés, C. (2009). Big constraints to small firms' growth? Business environment and employment growth across firms. World Bank Policy Research Working Paper 5032.

Beck, T., \& Demirguc-Kunt, A. (2006). Small and medium size enterprises: Access to finance as a growth constraint. Journal of Banking and Finance, 30(11), 2931-2943.

Beck, T., Demirguc-Kunt, A., \& Levine, R. (2003). Law, endowments, and finance. Journal of Financial Economics, 70, 137-181.

Berger, A. N., \& Udell, G. F. (1998). The economics of small business finance: The roles of private equity and debt markets in the financial growth cycle. Journal of Banking and Finance, 22(6), 613-673.

Buyinza F (2011),'Performance and survival of Ugandan manufacturing firms in the context of the East African community. Economic Policy Research Centre, Research series no 83.

Cabral, L., \& Mata, J. (2003). On the evolution of the firm size distribution: Facts and theory. American Economic Review, 93, $1075-1090$.

Cassar, G. (2004). The financing of business start-ups. Journal of Business Venturing, 19(2), 261-283.

Delmar, F, Davidsson, P. \& Gartner, W.B. (2003). Arriving at the high-growth firm.Journal of Business Venturing 18:189-216.

Demirgüç-Kunt, A., \& Maksimovic, V. (1998). Law, finance and firm growth. Journal of Finance, 53, 2107-2137.

Djankov, S., La Porta, R., Lopez-De-Silanes, F., \& Shleifer, A. (2002). The regulation of entry. Quarterly Journal of Economics, $117(1), 1-37$.

Dugassa, T. G. (2012). The context of entrepreneurship education in Ethiopian universities. Management Research Review, $35(3 / 4), 225-244$.

Egesa, K.A. (2010). Indigenous firms' survival in Uganda: Is there a role for increased technology use?. Bank of Uganda Working Paper.

EPRC. (2013). Uganda 2013 FinScope III survey report: Unlocking barriers to financial inclusion. Kampala: Economic Policy Research Centre (EPRC).

Galindo, A., \& Micco, A. (2005). Bank credit to small and medium-sized enterprises: The role of creditor protection. Working Paper No. 527, Washington, DC: Inter-American Development Bank, Research Department.

Galindo, A. J., \& Micco, A. (2007). Creditor protection and credit response to shocks. World Bank Economic Review, 21(3), 413-438.

GoU. (2014). Income tax act 2014. Kampala: Government of Uganda (GoU).

Hallward-Driemeier, M., \& Aterido, R. (2007). Comparing apples with apples: How to make (more) sense of subjective rankings of constraints to business. In Paper presented at the 2006 Oxford business and economics conference, Oxford University.

Huyghebaert, N., \& Van de Gucht, L. M. (2007). The determinants of financial structure: New insights from business start-ups. European Financial Management, 13(1), 101-133.

Ishengoma, E. K., \& Kappel, R. T. (2008). Business constraints and growth potential of micro and small manufacturing Enterprises in Uganda. GIGA. Working Paper No. 78. Available at SSRN: https://doi.org/10.2139/ssrn.1136816.

Jeong, H., \& Townsend, R. (2008). Growth and inequality: Model evaluation based on an estimation-calibration strategy. Macroeconomic Dynamics. 12(S2):231-284.

Kasekende, L., \& Opondo, H. (2003). Financing small and medium-scale enterprises (SMEs): Uganda's experience. BOU working paper, WP/03/01.

Klapper, L. F., Laeven, L., \& Rajan, R. G. (2004). Business regulations as a barrier to entrepreneurship. Journal of Financial Economics, 82(3), 591-629. 
Lakuma, C. P., Marty, R., \& Kuteesa, A. (2016). Survival analysis of regional unemployment in Uganda: Evidence from the Uganda National Panel Survey (UNPS). African Development Review, 28(1), 140-154.

Legas, H. (2015). Challenges to entrepreneurial success in sub-Saharan Africa: A comparative perspective. European Journal of Business and Management, 7(11):2015.

Obwona, M., \& Mugume, A. (2001). Credit accessibility and investment decisions in Uganda's manufacturing sector. African Review of Money Finance and Banking, 2001, pp.75-102.

O'Farrell, P. N. (1986). Entrepreneurs and Industrial Change (Irish Management Institute, Dublin).

Olawale, F., \& Garwe, D. (2010). Obstacles to the growth of new SMEs in South Africa: A principal component analysis approach. African Journal of Business Management, 4(5), 729-738.

Restuccia, D., \& Rogerson, R. (2008). Policy distortions and aggregate productivity with heterogeneous establishments. Review of Economic Dynamics, $11(4), 707-720$.

Shepherd, D., \& Wiklund, J. (2009). Are we comparing apples with apples or apples with oranges? Appropriateness of knowledge accumulation across growth studies. Entrepreneurship Theory and Practice, 33, 105-123.

Turyahikayo, E. (2015). Challenges faced by small and medium enterprises in raising finance in Uganda. International Journal of Public Administration and Management Research (IJPAMR), 3(2):21-33.

Tybout, J. R. (2000). Manufacturing firms in developing countries: How well do they do, and why? Journal of Economic Literature, 38(1), 11-44

UIA. (2008). Small and medium enterprises (SMEs) business guide. Uganda Investment Authority (UIA)

World Bank (2004). World Development Report 2005: A Better Investment Climate for Everyone. New York: Oxford University Press.

World Bank. (2009). Enterprise survey and Indicator surveys sampling methodology. Washington D.C.: World Bank Group. World Bank. (2014). Global financial development report 2014: Financial inclusion. Washington,D.C.: World Bank Group.

World Bank. (2014a). 2013 Uganda Enterprise survey: Country highlights. Washington D.C.: World Bank Group.

World Bank. (2017). From regulators to enablers: The role of city governments in economic development of greater Kampala. Washington D.C.: World Bank Group.

Zhou, H., \& de Wit, G. (2009). Determinants and dimensions of firm growth. In EIM research reports no. H200903. SCALES Scientific analysis of entrepreneurship and SMEs Zoetermeer: EIM business and policy research.

\section{Publisher's Note}

Springer Nature remains neutral with regard to jurisdictional claims in published maps and institutional affiliations.

\section{Submit your manuscript to a SpringerOpen ${ }^{\circ}$ journal and benefit from:}

- Convenient online submission

- Rigorous peer review

- Open access: articles freely available online

High visibility within the field

Retaining the copyright to your article

Submit your next manuscript at $\boldsymbol{\nabla}$ springeropen.com 